\title{
Antimicrobial Activity of Jambul (Syzygium cumini) Fruit Extract on Enteric Pathogenic Bacteria
}

\author{
Razoanul Haque, Mariya Kibtiya Sumiya, Najmuj Sakib, Omar Sadi Sarkar, \\ Tanjir Tarek Ibn Siddique, Saddam Hossain, Anisul Islam, Anowar Khasru Parvez, \\ Ali Azam Talukder, Shuvra Kanti Dey*
}

Department of Microbiology, Jahangirnagar University, Dhaka, Bangladesh

Email: *shuvradey@yahoo.com, *shuvradey@07.alumni.u-tokyo.ac.jp

How to cite this paper: Haque, R., Sumiya, M.K., Sakib, N., Sarkar, O.S., Siddique, T.T.I., Hossain, S., Islam, A., Parvez, A.K., Talukder, A.A. and Dey, S.K. (2017) Antimicrobial Activity of Jambul (Syzygium cumini) Fruit Extract on Enteric Pathogenic Bacteria. Advances in Microbiology, 7, 195204

https://doi.org/10.4236/aim.2017.73016

Received: January 15, 2017

Accepted: March 6, 2017

Published: March 9, 2017

Copyright $\odot 2017$ by authors and Scientific Research Publishing Inc. This work is licensed under the Creative Commons Attribution International License (CC BY 4.0).

http://creativecommons.org/licenses/by/4.0/

\begin{abstract}
Jambul (Syzygium cumini) contain several biological activities including anti diabetic, anti-inflammatory, gastroprotective and antibacterial activity. In this study, we investigated antibacterial activity of Jambul juice extract against some common enteric pathogens like Salmonella typhimurium, Shigella flexneri, Staphylococcus aureus, and ETEC (Entero toxigenic E. coli). Growth inhibition of these entero pathogenic bacteria was measured by growing in $\mathrm{Nu}$ trient Broth media supplemented with $0 \%, 5 \%, 10 \%$ and $25 \%$ juice extract and then plating on Nutrient Agar plate for colony count at 0, 24 and 48 hours time points. The effect of Jambul juice on the growth of Lactobacillus acidophilus and Lactobacillus bulgaricus were also investigated. We observed that the growth of Salmonella typhimurium, Shigella flexneri, Staphylococcus aureus, and ETEC were significantly inhibited by Jambul juice by 1 to $6 \operatorname{logs}(p<$ 0.001), and the growth of probiotics (Lactobacillus acidophilus and Lactobacillus bulgaricus) were not affected significantly. These findings indicate that Jambul juice have selective bactericidal effects against several enteric pathogens while beneficial species remain unaffected. To far our knowledge, this is the first report about the antibacterial activity of fruit juice in Bangladesh.
\end{abstract}

\section{Keywords}

Jambul, Foodborne Pathogens, Fruit Extract, Probiotics, Antimicrobial Activity

\section{Introduction}

Traditional use of plants and in treating disease has deep roots in the history of human races [1]. Plants are used in curing different infectious diseases like, diarrhea, malaria, burns, stomach disorders, gonorrhea etc. Scientists' Efforts in 
establishing plants with promising antimicrobial activity are being successful and yielding fruitful results [2] [3] [4] [5] [6]. Essential oils of plants and the antimicrobial properties of the low bush blueberry show antimicrobial activity against a wide range of microorganisms including antibiotic-resistant species of bacteria and fungi [7] [8] [9] [10]. Natural antimicrobials contain dynamic combinations of bioactive compounds to combat against the resistance of bacteria and also conserve probiotic species; so, they are attractive alternatives in many disease models [11].

Jambul (Syzygium cumini) also known as Syzygium jambolanum, Eugenia jambolanum and Eugenia cumini is an evergreen tropical tree in the flowering plant family Myrtaceae and native to Bangladesh, India, Nepal, Pakistan, Sri Lanka, the Philippines, and Indonesia. The plant is also known as, jam/kalojaam, Jambhul/jambu/jambula/jamboola, jamun, jamblang, jambolan, black plum, Damson plum, Duhat plum, Jambolan plum or Portuguese plum and so on.

Phytochemical screening of extracts of Syzygium cumini revealed that seed contains alkaloids, amino acids, phytosterols, saponins, steroids, tannins and triterpenoids etc. and leaf contains crude protein $9.1 \%$, fat $4.3 \%$, crude fiber $17 \%$, ash $7 \%$, calcium $1.3 \%$ and Phosphorus $0.19 \%$. These phytochemicals probably explain the plants medicinal properties [12]. The bark and seed have anti diabetic activity [13]; seed has anti-inflammatory activity [14], Radioprotective activity [15] [16], and antibacterial activity against E. coli, B subtilis, $P$. aeruginosa and S.aureus [17]; bark has gastroprotective and anti-ulcerogenic effects [18]; and leaf has anti-allergic [19] and anti-Vibrio cholera activity [20].

The edible portion of the fruit also contains some essential Phytochemicals: per 100 grams of edible portion contains: Moisture, $85.8 \mathrm{gm}$; ether extract, 0.15 gm; crude fiber, $0.3 \mathrm{gm}$; nitrogen, $0.129 \mathrm{gm}$; ash, $0.32 \mathrm{gm}$; calcium, $8.3 \mathrm{mg}$; phosphorus, $16.2 \mathrm{mg}$; iron, $1.62 \mathrm{mg}$; carotene, $0.004 \mathrm{mg}$; thiamine, $0.008 \mathrm{mg}$; riboflavin, $0.009 \mathrm{mg}$; niacin, $0.290 \mathrm{mg}$; total ascorbic acid, $5.7 \mathrm{mg}$ [21]. The composition of the edible portion suggests it to have some antimicrobial properties, and we should investigate the properties against the enteric pathogens as the fruit is taken as drink or directly. But if fruit extract destroys our beneficial normal flora of stomach, it won't be an effective antimicrobial agent, so bactericidal activity should be selective.

\section{Materials and Methods}

\subsection{Fruit Collection and Juice Extraction}

Fresh Jambul (Syzygium cumini) fruits were purchased from local market (Savar Bazar, Savar, Dhaka, Bangladesh). Fruits were checked to exclude the rotten, cracked or unripe ones and washed several times thoroughly to remove unwanted dirt. Then the selected fruits were added to a steam jacketed kettle; stirred continuously $(1000 \times \mathrm{g})$, kept for 3 minutes at $95^{\circ} \mathrm{C}$ to reduce the bacterial count of the surface. When the fruits were cooled down to $40^{\circ} \mathrm{C}$, the seeds were removed by using sterile forceps. These were taken and pressed in a hand operated squeezer to extract the juice; and the resultant juice was filtered through 
steurized double layers of cheesecloth. Juice was subsequently bottled in glass jars and stored at $4^{\circ} \mathrm{C}$.

\subsection{Bacterial Strains and Growth Conditions}

Strains of four potential enteric pathogens, Salmonella typhimurium, Shigella flexneri, Staphylococcus aureus, and ETEC (Enterotoxigenic E. coli) and two important probiotic bacteria, Lactobacillus acidophilus and, Lactobacillus bulgaricus were collected from the laboratory stock of dept. of microbiology, Jahangirnagar University, Savar, Dhaka, Bangladesh. Pathogenic bacteria were cultured on Nutrient Agar medium where the probiotic bacteria were cultured on Lactobacillus MRS (de Man, Rogosa, and Sharpe) Agar medium at $37^{\circ} \mathrm{C}$.

\subsection{Media Preparation}

Nutrient agar (Oxoid, UK)and Lactobacillus MRS Agar (Oxoid, UK) plates were used to subculture and to enumerate the bacterial count of pathogenic and probiotic bacteria respectively from the test tubes. Nutrient Broth (Oxoid, UK) and Lactobacillus MRS Broth media were used as the sole media to perform the growth effect test of pathogenic and probiotic bacteria respectively. All media were prepared by following the instructions of manufacturer, and sterilized by autoclaving at $121^{\circ} \mathrm{C}$ for 15 minutes.

\subsection{Preparation of Sole Test Media}

- Control media: Control media contain only $9 \mathrm{ml}$ of single strength broth media (Nutrient broth or Lactobacillus Broth) but no fruit juice.

- $5 \%$ juice media: $5 \%$ juice media are composed of $8.1 \mathrm{ml}$ of single strength, $0.45 \mathrm{ml}$ of double strength broth media and $0.45 \mathrm{ml}$ of fruit juice.

- $10 \%$ juice media: $10 \%$ juice media is made by mixing together $7.2 \mathrm{ml}$ of single strength, $0.9 \mathrm{ml}$ of double strength broth media and $0.9 \mathrm{ml}$ of fruit juice.

- $25 \%$ juice medium: $4.5 \mathrm{ml}$ of single strength, $2.25 \mathrm{ml}$ of double strength broth media and $2.25 \mathrm{ml}$ of fruit juice are the ingredients of $25 \%$ juice medium.

\subsection{Standardization of Inoculum}

Pathogenic bacteria were subcultured on fresh plates of Nutrient Agar at $37^{\circ} \mathrm{C}$ for 24 hours, and Probiotic bacteria were subcultured on fresh plates of Lactobacillus MRS Agar at $37^{\circ} \mathrm{C}$ for 48 hours. Colonies from these plates were washed out using $1 \mathrm{ml}$ of phosphate buffered saline (PBS) under laminar air flow cabinet. The optical density (OD) of the bacterial suspension was adjusted to an absorbance value of 0.10 at $600 \mathrm{~nm}$ on a spectrophotometer (Spectronic 200).

\subsection{Growth Effect Test}

After standardization, $1 \mathrm{ml}$ of bacterial suspension was added to each of the screw capped test tubes in the set of sole test media; Control medium, 5\% juice medium, $10 \%$ juice medium, and $25 \%$ juice medium. Then the set of sole test media were incubated at $37^{\circ} \mathrm{C}$ for 48 hours. Growth of bacteria was measured 
by counting the number of bacteria present in per $1 \mathrm{ml}$ of media at different time points $(0,24$, and 48 hours) by colony count method. In colony count method, serial dilutions were performed in PBS and plated on strain-specific agar to count bacterial colony forming units (CFU). Triplicate plates were prepared for each dilution in each trial and three trials were performed for each strain.

\subsection{Statistical Analysis}

SPSS version 12.0 (SPSS Inc., Chicago, IL, USA) was used for statistical analysis. The chi squared test $\left(\chi^{2}\right)$ was used to compare the effectiveness of Jambul fruit extract on enteric pathogenic bacteria. A p value less than 0.05 was considered to be significant.

\section{Result}

\subsection{Growth Effect Test of Shigella flexneri}

Antimicrobial activity of Jambul juice against Shigella flexneri was measured in liquid cultures by plate count method. Growth of the bacteria was reduced significantly after 24 hours and 48 hours of incubation in liquid bacterial culture media supplemented with different concentration of Jambul juice in each of the three trials. At 24 hours time point 5\% juice reduced the growth by about 2 logs, $10 \%$ juice reduced the growth by 2.65 logs, and $25 \%$ juice reduced the growth by 4.75 logs. And the inhibitory effect remained active even after 48 hours, though reduced slightly (at 5\% juice, $1.73 \mathrm{logs}$; at 10\% juice, $2.5 \mathrm{logs}$; and at $25 \%$ juice, 4 logs) (Table 1).

\subsection{Growth Effect Test of Staphylococcus aureus}

Growth of Staphylococcus aureus was reduced significantly after 24 hours and 48 hours of incubation in liquid bacterial culture media supplemented with different concentration of Jambul juice in each of the three trials. At 24 hours time point $5 \%$ juice reduced the growth by about $1 \log , 10 \%$ juice reduced the growth by $1 \mathrm{log}$, and $25 \%$ juice reduced the growth by 3 logs. And the inhibitory effect remained active after 48 hours, though reduced slightly at $25 \%$ juice $(2.3 \operatorname{logs})$ (Table 2).

\subsection{Growth Effect Test of ETEC}

In each of the three trials, growth of the bacteria was inhibited significantly after 24 hours incubation in liquid bacterial culture media supplemented with different concentration of Jambul juice in each of the three trials. At 24 hours time point $5 \%$ juice reduced the growth by about $1.5 \operatorname{logs}, 10 \%$ juice reduced the growth by $1.6 \mathrm{logs}$, and $25 \%$ juice reduced the growth by 2 logs. And the inhibitory effect remained active even after 48 hours (Table 3 ).

\subsection{Growth Effect Test of Salmonella typhi}

Growth of Salmonella typhi was reduced most significantly after incubation in 
liquid bacterial culture media supplemented with different concentration of Jambul juice in each of the three trials. At 24 hours time point 5\% juice reduced the growth by about 2.3 logs, $10 \%$ juice reduced the growth by 6.5 logs, and $25 \%$ juice reduced the growth 7 logs. At 48 hours of incubation, inhibitory effect of $5 \%$ juice was reduced by about $1 \log$, where $10 \%$ juice and $25 \%$ juice showed $>7$ logs reduction (Table 4).

Table 1. Effect of jambul juice on the growth of Shigella flexneri (cfu/ml).

\begin{tabular}{|c|c|c|c|c|c|c|c|c|}
\hline & $\mathrm{A}$ & $\mathrm{B}$ & $\mathrm{C}$ & $\mathrm{D}$ & $\mathrm{E}$ & $\mathrm{F}$ & G & $\mathrm{H}$ \\
\hline & $\begin{array}{l}\text { Type of } \\
\text { media }\end{array}$ & $\begin{array}{l}\text { Average count } \\
\text { after } 0 \text { hour } \\
\quad(\log 10)\end{array}$ & $\begin{array}{l}\text { Average count } \\
\text { after } 24 \text { hours } \\
(\log 10)\end{array}$ & $\begin{array}{l}\text { Average count } \\
\text { after } 48 \text { hours } \\
(\log 10)\end{array}$ & $\begin{array}{c}\text { Effect after } \\
24 \text { hours (C-B) }\end{array}$ & $\begin{array}{c}\text { Effect after } \\
48 \text { hours (D-B) }\end{array}$ & $\begin{array}{l}\text { Growth reduction } \\
\text { after } 24 \text { hours }\end{array}$ & $\begin{array}{c}\text { Growth reduction } \\
\text { after } 48 \\
\text { hours }\end{array}$ \\
\hline 1. & Control & 6.8 & 8.17 & 7.89 & +1.37 Log & +1.09 Log & & \\
\hline 2. & $5 \% \mathrm{JP}$ & 7.12 & 6.15 & 6.48 & $-0.62 \log$ & $-0.64 \log$ & $\mathrm{E} 1-\mathrm{E} 2=1.99 \mathrm{Log}$ & $\mathrm{F} 1-\mathrm{F} 2=1.73 \mathrm{Log}$ \\
\hline 4. & $25 \% \mathrm{JP}$ & 6.87 & 3.49 & 3.92 & $-3.38 \log$ & $-2.95 \log$ & $\mathrm{E} 1-\mathrm{E} 4=4.75 \log$ & $\mathrm{F} 1-\mathrm{F} 4=4.04 \mathrm{Log}$ \\
\hline
\end{tabular}

Table 2. Effect of jambul juice on the growth of Staphylococcus aureus $(\mathrm{cfu} / \mathrm{ml})$.

\begin{tabular}{|c|c|c|c|c|c|c|c|c|}
\hline & A & B & $\mathrm{C}$ & $\mathrm{D}$ & $\mathrm{E}$ & $\mathrm{F}$ & G & $\mathrm{H}$ \\
\hline & $\begin{array}{l}\text { Type of } \\
\text { media }\end{array}$ & $\begin{array}{l}\text { Average count } \\
\text { after } 0 \text { hour } \\
(\log 10)\end{array}$ & $\begin{array}{l}\text { Average count } \\
\text { after } 24 \text { hours } \\
\quad(\log 10)\end{array}$ & $\begin{array}{l}\text { Average count } \\
\text { after } 48 \text { hours } \\
\qquad(\log 10)\end{array}$ & $\begin{array}{c}\text { Effect after } \\
24 \text { hours (C-B) }\end{array}$ & $\begin{array}{c}\text { Effect after } \\
48 \text { hours (D-B) }\end{array}$ & $\begin{array}{l}\text { Growth reduction } \\
\text { after } 24 \text { hours }\end{array}$ & $\begin{array}{c}\text { Growth reduction } \\
\text { after } 48 \\
\text { hours }\end{array}$ \\
\hline 1. & Control & 6.89 & 8.51 & 8.53 & $+1.62 \log$ & +1.64 Log & & \\
\hline 2. & $5 \% \mathrm{JP}$ & 6.92 & 7.53 & 7.56 & $+0.61 \log$ & $+0.64 \log$ & $\mathrm{E} 1-\mathrm{E} 2=1.01 \mathrm{Log}$ & $\mathrm{F} 1-\mathrm{F} 2=1.0 \mathrm{Log}$ \\
\hline 3. & $10 \% \mathrm{JP}$ & 6.84 & 7.33 & 7.24 & $+0.49 \log$ & $+0.4 \log$ & $\mathrm{E} 1-\mathrm{E} 3=1.13 \mathrm{Log}$ & $\mathrm{F} 1-\mathrm{F} 3=1.24 \mathrm{Log}$ \\
\hline 4. & $25 \% \mathrm{JP}$ & 6.73 & 5.44 & 6.02 & $-1.29 \log$ & $-0.71 \log$ & $\mathrm{E} 1-\mathrm{E} 4=2.91 \mathrm{Log}$ & $\mathrm{F} 1-\mathrm{F} 4=2.35 \log$ \\
\hline
\end{tabular}

Table 3. Effect of jambul juice on the growth of ETEC (cfu/ml).

\begin{tabular}{|c|c|c|c|c|c|c|c|c|}
\hline & A & B & $\mathrm{C}$ & $\mathrm{D}$ & $\mathrm{E}$ & $\mathrm{F}$ & G & $\mathrm{H}$ \\
\hline & $\begin{array}{l}\text { Type of } \\
\text { media }\end{array}$ & $\begin{array}{l}\text { Average count } \\
\text { after } 0 \text { hour } \\
(\log 10)\end{array}$ & $\begin{array}{l}\text { Average count } \\
\text { after } 24 \text { hours } \\
\quad(\log 10)\end{array}$ & $\begin{array}{l}\text { Average count } \\
\text { after } 48 \text { hours } \\
(\log 10)\end{array}$ & $\begin{array}{c}\text { Effect after } \\
24 \text { hours (C-B) }\end{array}$ & $\begin{array}{c}\text { Effect after } \\
48 \text { hours (D-B) }\end{array}$ & $\begin{array}{l}\text { Growth reduction } \\
\text { after } 24 \text { hours }\end{array}$ & $\begin{array}{c}\text { Growth reduction } \\
\text { after } 48 \\
\text { hours }\end{array}$ \\
\hline 1. & Control & 6.89 & 8.43 & 8.12 & +1.54 Log & $+1.23 \log$ & & \\
\hline 2. & $5 \% \mathrm{JP}$ & 6.89 & 7.02 & 6.90 & $+0.13 \log$ & $+0.01 \log$ & $\mathrm{E} 1-\mathrm{E} 2=1.51 \mathrm{Log}$ & $\mathrm{F} 1-\mathrm{F} 2=1.22 \mathrm{Log}$ \\
\hline 4. & $25 \% \mathrm{JP}$ & 6.9 & 6.47 & 6.15 & $-0.43 \log$ & $-0.54 \log$ & $\mathrm{E} 1-\mathrm{E} 4=2.0 \mathrm{Log}$ & $\mathrm{F} 1-\mathrm{F} 4=1.77 \log$ \\
\hline
\end{tabular}

Table 4. Effect of jambul juice on the growth of Salmonella typhi (cfu/ml).

\begin{tabular}{|c|c|c|c|c|c|c|c|c|}
\hline \multirow{2}{*}{\multicolumn{2}{|c|}{$\begin{array}{l}\text { Type of } \\
\text { media }\end{array}$}} & \multirow{2}{*}{$\begin{array}{c}\text { B } \\
\text { Average count } \\
\text { after } 0 \text { hour } \\
(\log 10)\end{array}$} & \multirow{2}{*}{$\begin{array}{c}\text { C } \\
\text { Average count } \\
\text { after } 24 \text { hours } \\
(\log 10)\end{array}$} & \multirow{2}{*}{$\begin{array}{l}\text { D } \\
\text { Average count } \\
\text { after } 48 \text { hours } \\
(\log 10)\end{array}$} & \multirow{2}{*}{$\begin{array}{c}\text { E } \\
\text { Effect after } \\
24 \text { hours }(\mathrm{C}-\mathrm{B})\end{array}$} & \multirow{2}{*}{$\begin{array}{c}\text { F } \\
\text { Effect after } \\
48 \text { hours (D-B) }\end{array}$} & \multirow{2}{*}{$\begin{array}{c}\text { G } \\
\text { Growth reduction } \\
\text { after } 24 \text { hours }\end{array}$} & \multirow{2}{*}{$\begin{array}{c}\mathrm{H} \\
\text { Growth reduction } \\
\text { after } 48 \\
\text { hours }\end{array}$} \\
\hline & & & & & & & & \\
\hline 1. & Control & 6.48 & 7.39 & 7.71 & $+0.91 \log$ & $+1.23 \log$ & & \\
\hline 2. & $5 \% \mathrm{JP}$ & 6.68 & 5.28 & 5.75 & $-1.4 \log$ & $-0.93 \log$ & $\mathrm{E} 1-\mathrm{E} 2=2.31 \mathrm{Log}$ & $\mathrm{F} 1-\mathrm{F} 2=1.22 \mathrm{Log}$ \\
\hline 4. & $25 \% \mathrm{JP}$ & 6.66 & $0^{*}$ & $0^{*}$ & $-6.36 \log$ & $<-6 \log$ & $\mathrm{E} 1-\mathrm{E} 4=7.27 \mathrm{Log}$ & $\mathrm{F} 1-\mathrm{F} 4=>7 \log$ \\
\hline
\end{tabular}

* $=$ Below the detection level $(<100 \mathrm{cfu} / \mathrm{ml})$. 


\subsection{Growth Effect Test of Lactobacillus acidophilus}

Effect of Jambul juice on the growth of Lactobacillus acidophilus was measured in liquid cultures by plate count method. Growth of the bacteria was not reduced but stimulated slightly (about $0.2 \mathrm{log}$ ), which is not also significant after 24 hours and 48 hours of incubation (Table 5).

\subsection{Growth Effect Test of Lactobacillus bulgaricus}

Effect of Jambul juice on the growth of Lactobacillus bulgaricus was also measured in liquid cultures by plate count method. Growth of the bacteria was not reduced nor stimulated by significantly after 24 hours and 48 hours of incubation in liquid culture media supplemented with different concentration of Jambul juice in each of the three trials. The inhibition or stimulation rate was negligible (between $+0.1 \log$ and $-0.1 \log$ ) in each of the three trials at both 24 hours and 48 hours time point (Table 6).

\section{Discussion}

In recent years, food borne illness like gastroenteritis, diarrhoea etc. are increasing day by day as our food habit and livelihood has changed a lot [22] [23]. Salmonella typhimurium, Shigella flexneri, Staphylococcus aureus, and ETEC (Entero toxigenic E. coli) are the common pathogens those cause food borne intestinal disease. It's a major challenge to control those organisms and their infection. All natural organic antimicrobial agents have the potential to be an alternative way to control infection with food borne bacteria [24] [25].

No significant study has been performed yet to evaluate the role of jambul juice on the growth of pathogenic bacteria and beneficial microflora. Our study

Table 5. Effect of jambul juice on the growth of Lactobacillus acidophilus (cfu/ml).

\begin{tabular}{|c|c|c|c|c|c|c|c|c|}
\hline & A & B & $\mathrm{C}$ & $\mathrm{D}$ & $\mathrm{E}$ & $\mathrm{F}$ & G & $\mathrm{H}$ \\
\hline & $\begin{array}{l}\text { Type of } \\
\text { media }\end{array}$ & $\begin{array}{l}\text { Average count } \\
\text { after } 0 \text { hour } \\
(\log 10)\end{array}$ & $\begin{array}{l}\text { Average count } \\
\text { after } 24 \text { hours } \\
(\log 10)\end{array}$ & $\begin{array}{l}\text { Average count } \\
\text { after } 48 \text { hours } \\
(\log 10)\end{array}$ & $\begin{array}{c}\text { Effect after } \\
24 \text { hours (C-B) }\end{array}$ & $\begin{array}{c}\text { Effect after } \\
48 \text { hours (D-B) }\end{array}$ & $\begin{array}{c}\text { Growth reduction } \\
\text { after } 24 \text { hours }\end{array}$ & $\begin{array}{c}\text { Growth reduction } \\
\text { after } 48 \\
\text { hours }\end{array}$ \\
\hline 1. & Control & 5.82 & 8.92 & 9.06 & +3.1 Log & +3.24 Log & & \\
\hline 2. & $5 \% \mathrm{JP}$ & 6.05 & 8.87 & 9.1 & $+2.82 \log$ & +3.05 Log & $\mathrm{E} 1-\mathrm{E} 2=0.28 \mathrm{Log}$ & $\mathrm{F} 1-\mathrm{F} 2=0.19 \mathrm{Log}$ \\
\hline 4. & $25 \% \mathrm{JP}$ & 6.03 & 8.81 & 9.1 & $+2.78 \log$ & +3.07 Log & $\mathrm{E} 1-\mathrm{E} 4=0.32 \log$ & $\mathrm{F} 1-\mathrm{F} 4=0.17 \mathrm{Log}$ \\
\hline
\end{tabular}

Table 6. Effect of jambul juice on the growth of Lactobacillus bulgaricus (cfu/ml).

\begin{tabular}{|c|c|c|c|c|c|c|c|c|}
\hline & A & B & C & $\mathrm{D}$ & $\mathrm{E}$ & $\mathrm{F}$ & G & $\mathrm{H}$ \\
\hline & $\begin{array}{l}\text { Type of } \\
\text { media }\end{array}$ & $\begin{array}{l}\text { Average count } \\
\text { after } 0 \text { hour } \\
(\log 10)\end{array}$ & $\begin{array}{l}\text { Average count } \\
\text { after } 24 \text { hours } \\
(\log 10)\end{array}$ & $\begin{array}{l}\text { Average count } \\
\text { after } 48 \text { hours } \\
(\log 10)\end{array}$ & $\begin{array}{c}\text { Effect after } \\
24 \text { hours (C-B) }\end{array}$ & $\begin{array}{l}\text { Effect after } \\
48 \text { hours } \\
\text { (D-B) }\end{array}$ & $\begin{array}{l}\text { Growth reduction } \\
\text { after } 24 \text { hours }\end{array}$ & $\begin{array}{c}\text { Growth reduction } \\
\text { after } 48 \\
\text { hours }\end{array}$ \\
\hline 1. & Control & 6.23 & 8.59 & 8.85 & +2.36 Log & $+2.62 \log$ & & \\
\hline 2. & $5 \% \mathrm{JP}$ & 6.23 & 8.66 & 8.81 & +2.43 Log & $+2.58 \log$ & $\mathrm{E} 1-\mathrm{E} 2=-0.07 \log$ & $\mathrm{F} 1-\mathrm{F} 2=0.04 \mathrm{Log}$ \\
\hline 4. & $25 \% \mathrm{JP}$ & 6.16 & 8.52 & 8.91 & +2.36 Log & +2.75 Log & $\mathrm{E} 1-\mathrm{E} 4=0 \mathrm{Log}$ & $\mathrm{F} 1-\mathrm{F} 4=-0.13 \log$ \\
\hline
\end{tabular}


demonstrates clear evidence that jambul juice has selective bactericidal effects against several foodborne pathogens while Lactobacillus species remained unaffected. In the present study, we have shown that, different concentrations of jambul juice have strong antimicrobial effect on the growth of Salmonella typhimurium, Shigella flexneri, Staphylococcus aureus, and ETEC (reduced the growth by 1 log to 7 logs). This result supports the study of Biswas et al. [26], who reported blueberry juice to inhibit the growth of $S$. typhimurium, Campylobacter jejuni, L. monocytogenes, and E. coli O157:H7; the study of Puupponen-Pimiä et al. [27] who reported that phenolic compounds of berries, especially ellagitannins inhibited the growth of gram negative bacteria like Staphylococcus, Salmonella, and Listeria; and Park et al. [28] who demonstrated that both ethanol and water extracts of blueberry and muscadine significantly inhibited the growth of four Salmonella strains and one Listeria strain [26] [27] [28] [29]. The possible reason of this bactericidal activity of jambul juice could be the membrane interface interaction of phenolics, anthocyanins, and proanthocyanidins, due to their partial hydrophobicity which allow them to bind to the outer membrane causing changes in fluidity [24] [30]. Many recent studies showed that the growth of probiotic bacteria, like Lactobacillus and Bifidobacterium remained unaffected by the presence of phenolic compounds found in the berries [24] [26] [27]. Similarly, our study showed that growth of Lactobacillus acidophilus and Lactobacillus bulgaricus remained unaffected in each concentrations of juice.

Moreover, ensuring the safety of the food supply chain has become more difficult due to the resurgence of multidrug resistant strains of foodborne pathogens [31] [32]. Natural antimicrobial agents like jambul juice may be an effective alternative choice against the bacterial pathogens that are resistant to available drugs. So, further study may be designed to evaluate the antimicrobial activity of jambul juice against the multi-drug resistant strains of food borne pathogens. Food borne and enteric pathogens moreover the resurgence of drug resistant strains has made it a great challenge to control the food safety. Jambul juice can be a good source of alternative natural drugs against these pathogens. Jambul is very cheap and available in this region (Indian subcontinent). Considering the antimicrobial and nutritional activity of Jambul juice, large scale industrial production of Jambul juice will be possible. By following this study method, investigation of antimicrobial activity of other natural foods and fruits will be possible. On the other hand people's consciousness about enteric diseases and benefit of natural fruit consumption in preventing these types of disease will be increased day by day in developing countries like Bangladesh. The result of this study is just a pointer to new sources of novel drugs and natural antibiotics. Studies should also be done on understanding which of the phytochemicals are responsible for the observed beneficial effects and their mechanism of action. In vivo tests in animal or human model may also be done for better understanding of the test result. 


\section{Acknowledgements}

We would like to thanks all laboratory staffs, Department of Microbiology, Jahangirnagar University to provide kind support during this research work. This study was partly supported by grants-in-aid from University Grants Commission, Bangladesh. We would also like to thanks HEQEP project (CP-3413) for giving the publication charge.

\section{References}

[1] Grabley, S. and Thiericke, R. (1999) Bioactive Agents from Natural Sources: Trends in Discovery and Application. Advances in Biochemical Engineering and Biotechnology, 64, 101-154. https://doi.org/10.1007/3-540-49811-7_4

[2] Ndukwe, K.C., Okeke, I.N., Lamikanra, A., Adesina, S.K. and Aboderin, O. (2005) Antibacterial Activity of Aqueous Extracts of Selected Chewing Sticks. Journal of Contemporary Dental Practice, 15, 86-94.

[3] Adedayo, O., Anderson, W.A., Snieckus, M.Y., Patil, V. and Kolawole, D.O. (2001) Phytochemistry and Antibacterial Activity of Sennaalata Flower. Journal of Pharmaceutical Biology, 39, 408-412. https://doi.org/10.1076/phbi.39.6.408.5880

[4] Perumal, R.S. and Ignacimuthu, S. (2001) Antibacterial Effect of the Bark of Terminalia arjuna: Justification of Folklore Beliefs. Journal of Pharmaceutical Biology, 39, 417-420. https://doi.org/10.1076/phbi.39.6.417.5876

[5] Oyagade, J.O., Awotoye, O.O., Adewunmi, J.T. and Thorpe, H.T. (1999) Antimicrobial Activity of Some Nigerian Medicinal Plants. I. Screening for Antibacterial Activity. Bioscience Biotechnology Research Communications, 11, 193-197.

[6] Olukoya, D.K., Odugbemi, T.O. and Bamgbose, S.O.A. (1986) Some Aspects of Traditional Therapy of Gonorrhoea in Lagos, Nigeria. Journal of Research in Ethno-Medicine, 1, 26-29.

[7] Lacombe, A., Wu, V.C., White, J., Tadepalli, S. and RE, E.E. (2012) The Antimicrobial Properties of the Low Bush Blueberry (Vaccinium angustifolium) Fractional Components against Foodborne Pathogens and the Conservation of Probiotic Lactobacillus rhamnosus. Food Microbiology, 30, 124-131.

https://doi.org/10.1016/j.fm.2011.10.006

[8] Carson, C.F. and Riley, T.V. (1995) Antimicrobial Activity of the Major Components of the Essential Oil of Melaleuca alternifolia. Journal of Applied Microbiology, 78, 264-269.

[9] El-Kabouss, A., Charrouf, Z., Faid, M., Garneau, F. and Collin, G. (2002) Chemical Composition and Antimicrobial Activity of the Leaf Essential Oil Argania spinosa L. Skeels. Journal of Essential Oil Research, 14, 147-149. https://doi.org/10.1080/10412905.2002.9699801

[10] El-Kady, I.A., El-Maraghy, S.S.M. and Mostafa, E.M. (1993) Antibacterial and Antidermatophyte Activities of Some Essential Oils from Spices. Qatar University Science Journal, 13, 63-69.

[11] Nohynek, L.J., Alakomi, H.L., Kahkonen, M.P. Heinonen, M., Helander, I.M., Oksman-Caldentey, K.M. and Puuponen-Pimia, R.H. (2006) Berry Phenolics: Antimicrobial Properties and Mechanisms of Action against Severe Human Pathogens. Nutrition and Cancer, 54, 11-32. https://doi.org/10.1207/s15327914nc5401_4

[12] Kumar, A., Ilavarasan, R., Jayachandran, T., Deecaraman, M., Mohah, K.R., Aravindan, P., Padmanabhan, N. and Krishan, M.R.V. (2008) Anti-Inflammatory Activity of Syzygium cumini Seed. African Journal of Biotechnology, 7, 941-943. 
[13] Rosély, D., Schossler, C., Melazzo, C., Sônia, M., Almeida, C., Luz, D., Filappi, A., Prestes, D, Ferreira, A., Silveira, D. and Cecim, M. (2004) Syzygium cumini and the Regeneration of Insulin Positive Cells from the Pancreatic Duct. Brazilian Journal of Veterinary Research and Animal Science, 41, 236-239.

[14] Shinde, J., Taldone, T., Barletta, M., Kunaparaju, N., Hu, B., Kumar, S., Placido, J. and Zito, S. (2008) Alpha-Glucosidase Inhibitory Activity of Syzygium cumini (Linn.) Skeels Seed Kernel in Vitro and in Goto-Kakizaki (GK) Rats. Carbohydrate Research, 343, 1278-1281. https://doi.org/10.1016/j.carres.2008.03.003

[15] Kumar, A., Ilavarasan, R., Jayachandran, T., Decaraman, M., Aravindhan, P., Padmanabhan, N. and Krishnan, M.R.V. (2009) Phytochemicals Investigation on a Tropical Plant, Syzygium cumini from South India. Pakistan Journal of Nutrition, 8 , 83-85. https://doi.org/10.3923/pjn.2009.83.85

[16] Jagetia, G.C., Baliga, M.S. and Venkatesh, P. (2005) Influence of Seed Extract of Syzygium cumini (Jamun) on Mice Exposed to Different Doses of G-Radiation. Journal of Radiation Research, 46, 59-65. https://doi.org/10.1269/jrr.46.59

[17] Roy, A., Bhattacharya, S., Pandey, J.N. and Biswas, M. (2011) Anti-Inflammatory Activity of Syzygium cumini Leaf against Experimentally Induced Acute and Chronic Inflammations in Rodents. Alternative Medicine Studies, 1, 23-25. https://doi.org/10.4081/ams.2011.e6

[18] Ramirez, R.O. and Roa, C.C. (2003) The Gastro Protective Effect of Tannins Extracted from Duhat (Syzygium cumini Skeels) Bark on $\mathrm{HCl} /$ Ethanol Induced Gastric Mucosal Injury in Sprague-Dawley Rats. Clinical Hemorheology and Microcirculation, 29, 253-261.

[19] Alviano, W.S., et al. (2005) Antimicrobial Activity of Croton Cajucara Benth Linalool-Rich Essential Oil on Artificial Biofilms and Planktonic Microorganisms. Oral Microbiology and Immunology, 20, 101-105. https://doi.org/10.1111/j.1399-302X.2004.00201.x

[20] Ahsan, N., Paul, N., Islam, N. and Akhand, A.A. (2012) Leaf Extract of Syzygium cumini Shows Anti-Vibrio Activity Involving DNA Damage. Dhaka University Journal of Pharmaceutical Sciences, 11, 25-28. https://doi.org/10.3329/dujps.v11i1.12483

[21] Munsell, H., Williams, L., Guild, L., Troescher, C., Nightingale, G. and Harris, R. (1949) Composition of Food Plants of Central America. Food Research, 14, 144 164. https://doi.org/10.1111/j.1365-2621.1949.tb16218.x

[22] Garcia-Huidorbo, D., Carreno, M., Alcayaga, S. and Ulloa, J. (2012) Clinical and Epidemiological Description of Severe Outbreak of Foodborne Infection by Salmonella enteritidis. Revista Chilena de Infectología, 29, 132-137.

[23] World Health Organization (2011) Food Safety and Foodborne Illness. Fact Sheet No. 237. http://www.who.int/mediacentre/factsheets/fs237/en/

[24] Lacombe, A., Wu, V.C.H., Tyler, S. and Edwards, K. (2010) Antimicrobial Action of the American Cranberry Constituents: Phenolics, Anthocyanins, and Organic Acids, against Escherichia coli O157:H7. International Journal of Food Microbiology, 139, 102-107. https://doi.org/10.1016/j.ijfoodmicro.2010.01.035

[25] Burt, S. (2004) Essential Oils: Their Antibacterial Properties and Potential Applications in Foods-A Review. International Journal of Food Microbiology, 94, 223 253. https://doi.org/10.1016/j.ijfoodmicro.2004.03.022

[26] Biswas, D., Nathan, E.W., Corliss, A.O., Arunachalam, M., Jody, M.L., Crandall, P.G. and Ricke, S. (2012) Pasteurized blueberry (Vaccinium corymbosum) Juice Inhibits Growth of Bacterial Pathogens in Milk but Allows Survival of Probiotic Bacteria. Journal of Food Safety, 32, 204-209. 
https://doi.org/10.1111/j.1745-4565.2012.00369.x

[27] Puupponen-Pimiä, R., Nohynek, L., Hartmann-Schmidlin, S., Kahkonen, M., Heinonen, M. and Oksman-Caldentey, K.M. (2005) Berry Phenolics Inhibit the Growth of Intestinal Pathogens. Journal of Applied Microbiology, 98, 991-1000. https://doi.org/10.1111/j.1365-2672.2005.02547.x

[28] Park, Y.J., Biswas, R., Phillip, R.D. and Chen, J.R. (2011) Antibacterial Activities of Blueberry and Muscadine Phenolic Extracts. Journal of Food Science, 46, M101M105. https://doi.org/10.1111/j.1750-3841.2010.01974.x

[29] Puupponen-Pimiä, R., Nohynek, L., Hartmann-Schmidlin, S., KÄhkÖnen, M., Heinonen, M. and Oksman-Caldentey, K.M. (2005) Berry Phenolics Inhibit the Growth of Intestinal Pathogens. Journal of Applied Microbiology, 98, 991-1000. https://doi.org/10.1111/j.1365-2672.2005.02547.x

[30] Kwon, Y.I., Aposttolidis, E., Labbe, R.G. And Shetty, K. (2007) Inhibition of Staphylococcus aureus by Phenolic Phytochemicals of Selected Clonal Herbs Species of Lamiaceae Family and Likely Mode of Action through Proline Oxidation. Food Biotechnology, 21, 71-89. https://doi.org/10.1080/08905430701191205

[31] Mirzaagha, P., Louie, M., Sharma, R., Yanke, L.J., Topp, E. and Mcallister, T.A. (2011) Distribution and Characterization of Ampicillin-and Tetracycline-Resistant Escherichia coli from Feedlot Cattle Fed Subtherapeutic Antimicrobials. BMC Microbiology, 11, 78. https://doi.org/10.1186/1471-2180-11-78

[32] Cook, A., Reid-Smith, R.J., Irwin, R.J., Mcewen, S.A., Young, V. and Ribble, C. (2011) Antimicrobial Resistance in Campylobacter, Salmonella, and Escherichia coli Isolated from Retail Grain-Fed Veal Meat from Southern Ontario, Canada. Journal of Food Protection, 74, 1245-1251. https://doi.org/10.4315/0362-028X.JFP-10-483

Submit or recommend next manuscript to SCIRP and we will provide best service for you:

Accepting pre-submission inquiries through Email, Facebook, LinkedIn, Twitter, etc. A wide selection of journals (inclusive of 9 subjects, more than 200 journals)

Providing 24-hour high-quality service

User-friendly online submission system

Fair and swift peer-review system

Efficient typesetting and proofreading procedure

Display of the result of downloads and visits, as well as the number of cited articles

Maximum dissemination of your research work

Submit your manuscript at: http://papersubmission.scirp.org/

Or contact aim@scirp.org 